\title{
sGC redox regulation and asthma
}

\author{
Dennis J Stuehr ${ }^{1 *}$, Arnab Ghosh ${ }^{1}$, Cynthia J Koziol-White ${ }^{2}$, Kewal Asosingh ${ }^{1}$, Georgina Cheng ${ }^{1}$, Lisa Ruple ${ }^{1}$ \\ Jennifer Rodgers ${ }^{1}$, Dieter Groneberg ${ }^{3}$, Andreas Friebe ${ }^{3}$, Johannes-Peter Stasch ${ }^{4}$, Reynold A Panettieri ${ }^{2}$, \\ Mark A Aronica1 ${ }^{5}$, Serpil C Erzurum ${ }^{1,5}$ \\ From 7th International Conference on cGMP Generators, Effectors and Therapeutic Implications \\ Trier, Germany. 19-21 June 2015
}

Asthma is defined by airway inflammation and hyperresponsiveness, and contributes to morbidity and mortality worldwide. Although bronchodilation is a cornerstone of asthma treatment, current bronchodilators become ineffective with time and with worsening asthma severity. We investigated an alternative pathway for bronchodilation that involves activating the airway smooth muscle enzyme, soluble guanylate cyclase (sGC).

The pharmacologic sGC stimulator BAY 41-2272 or a NO donor each triggered a dose-dependent bronchodilation in precision cut human lung slices from healthy donors and in mouse tracheal rings, whereas BAY 60-2770 was a less effective bronchodilator in these circumstances. Neither NO nor BAY 41-2272 relaxed tracheal rings obtained from sGC-/- mice. This established the NO-sGC pathway can trigger bronchodilation in healthy airway. In live animal studies, a single intra-tracheal administration of either BAY 41-2272 or BAY 60-2770 reversed the airway hyper-responsiveness that had developed in mice with allergic asthma and restored their normal lung function. The sGC recovered from the mouse asthmatic lungs displayed three hallmarks of oxidative damage that render it NO-insensitive, and identical changes were found to occur in sGC obtained from human lung slices or from cultured cells that had been exposed to low chronic NO. Our findings reveal how allergic inflammation in asthma, and its resulting airway inflammation and excessive $\mathrm{NO}$ production, impede the natural NO-sGC-based bronchodilation pathway, and suggest that pharmacologic sGC stimulants or activators can provide a novel therapeutic approach to achieve bronchodilation despite this loss.

\footnotetext{
* Correspondence: stuehrd@ccf.org

'Department of Pathobiology, Lerner Research Institute, Cleveland Clinic, Cleveland, Ohio 44195, USA

Full list of author information is available at the end of the article
}

\section{Authors' details}

'Department of Pathobiology, Lerner Research Institute, Cleveland Clinic, Cleveland, Ohio 44195, USA. University of Pennsylvania Medical Center, Pulmonary, Allergy, and Critical Care Division, Philadelphia, PA 19104, USA. ${ }^{3}$ Institute of Vegetative Physiology, Universität Würzburg, D-97070 Würzburg,

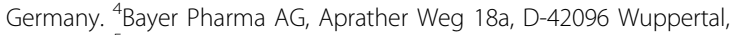

Germany. ${ }^{5}$ Respiratory Institute, Cleveland Clinic, Cleveland, Ohio 44195, USA.

Published: 2 September 2015

doi:10.1186/2050-6511-16-S1-A26

Cite this article as: Stuehr et al: sGC redox regulation and asthma. BMC Pharmacology and Toxicology 2015 16(Suppl 1):A26.

\author{
Submit your next manuscript to BioMed Central \\ and take full advantage of: \\ - Convenient online submission \\ - Thorough peer review \\ - No space constraints or color figure charges \\ - Immediate publication on acceptance \\ - Inclusion in PubMed, CAS, Scopus and Google Scholar \\ - Research which is freely available for redistribution \\ Submit your manuscript at \\ www.biomedcentral.com/submit
}

() Biomed Central

(C) 2015 Stuehr et al. This is an Open Access article distributed under the terms of the Creative Commons Attribution License (http:// creativecommons.org/licenses/by/4.0), which permits unrestricted use, distribution, and reproduction in any medium, provided the original work is properly cited. The Creative Commons Public Domain Dedication waiver (http://creativecommons.org/publicdomain/ zero/1.0/) applies to the data made available in this article, unless otherwise stated. 